\title{
Impact of Environmental Education Kit on Students' Environmental Literacy
}

\author{
Misbahul Jannah $^{1,2}$, Lilia Halim ${ }^{1}$, T. Subahan Mohd Meerah ${ }^{1} \&$ Muhammad Fairuz $^{1}$ \\ ${ }^{1}$ Faculty of Education, Universiti Kebangsaan Malaysia, Selangor, Malaysia \\ ${ }^{2}$ Faculty of Education, IAIN Ar-Raniry, Banda Aceh, Indonesia \\ Correspondence: Lilia Halim, Faculty of Education, Universiti Kebangsaan Malaysia, 43600 UKM Bangi, \\ Selangor, Malaysia. Tel: 60-3-8921-6230/6231. E-mail: profdrlilia@gmail.com
}

\author{
Received: August 1, 2013 Accepted: August 16, 2013 Online Published: August 30, 2013 \\ doi:10.5539/ass.v9n12p1 URL: http://dx.doi.org/10.5539/ass.v9n12p1
}

\begin{abstract}
To support the implementation of environmental education (EE) across the curriculum, WWF-Malaysia has developed Environmental Education Kit (EE-Kit) to increase the level of environmental literacy of students. Environmental literacy is a part of EE that refers to knowledge, awareness, behavior, environmental attitude and participation. The purpose of this study was to determine the level of environmental literacy amongst students based on gender and stream of study also student perception on the use of EE-Kit. 345 secondary school students age 14 and 16 years old participated in this survey study and 10 students were interviewed. An EE teaching kit was used to teach the students. Using descriptive and inferential statistics it was determined that there was a significant difference in the level of environmental literacy based on gender, whereas for class stream reveals no significant difference. However, the level on environmental literacy based on gender and class stream are still at the moderate and low level. It also was found that knowledge of and about the environment is at low level as compared to environment attitude, behavior, awareness and environment participation. It appears that perception and students practice related to positive behavior towards environment exist despite the lack of knowledge in and on environment. However, that does not guarantee students to manage the environment effectively. Implication of this study suggests that knowledge, attitude and developing positive behavior towards environment need to be developed in an integrated way. The study recommends that the inculcation of environmental literacy through the use of EE-Kit among students in rural areas needs to be improved in building citizens who can preserve and conserve the environment.
\end{abstract}

Keywords: environmental education kit, environmental literacy, seconday school students, science and arts stream, students perception

\section{Introduction}

The environmental education (EE) has been recognized and accepted globally as an effort to protect the environment and sustainable development (Zurina \& Norjan, 2003; Moroye, 2005) when it is observed to have the potential to assist the future generation to manage life and to establish a prosperous future (Perikleous, 2004). Moreover, EE will also raise the awareness, knowledge and contribute to shift of attitudinal and behavioral aspect towards the environment and its sustainability in the society (Moroye, 2005; Leeming et al., 1997; Eagles \& Demare, 1999; Callicot, 2000; NAAEE, 2001; WWF-Malaysia, 2008, 2009; Talero, 2004). Realizing the importance of sustainable development, EE was implemented into Malaysian primary and the secondary school curriculum since 1998. Besides Malaysia, other countries, such as, Australia, the United States and Japan also use similar approaches in introducing the EE in their respective countries.

In the context of EE, the environmental literacy refers to knowledge and awareness of environmental issue. It also refers to positive involvement and attitude among students towards environment. High level of environmental literacy reflects the effectiveness implementation of EE (Leeming et al., 1997; Eagles \& Demare, 1999). The environmental literacy also includes high intrinsic values concerning the environment and its effects on the human life (Habibah \& Punitha, 2009; Taraban et al., 2007). Based on the concept of environmental literacy explained, environmental literacy is a part of EE that refers to knowledge, awareness, behavior, environment attitude and environment involvement. Interaction between the components of environmental literacy is illustrated in Figure 1. 


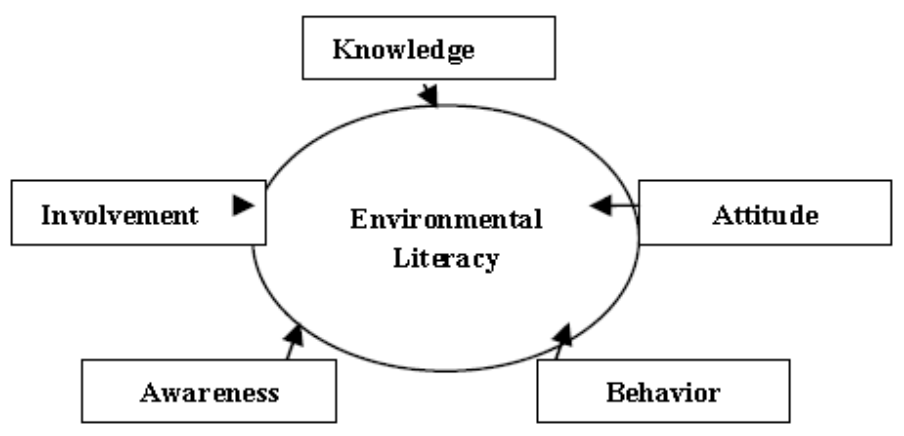

Figure 1. Components of environmental literacy

Environmental literacy is the ultimate goal and the best way to address environmental issues. Environmental literacy also was introduced as a part of EE which consists of five elements namely, knowledge, attitude, behavior, awareness and environmental involvement (McBecth et al., 2008; Negev et al., 2008; Erdogan et al., 2009; McBecth \& Volk, 2010).Based on the description of environmental literacy in chapter 36 agenda 21 , effective implementation of an environment teaching is to produce students who have experience an attitudinal change so that they are capable of evaluating and showing their concern towards Sustainable Development (UNEP, 1992; Mc Keown, 2002).

Therefore, in making decision toward country development, students should acquire a consistent and high level of environmental literacy. However, based on previous research, the level of environmental literacy amongst students in Australia, the United States, China, Singapore and New Zealand is still unsatisfactory. According to Ridener (1997) most of the students in Australia have a high environmental awareness, but the students' involvement in environmental activities is still at the moderate and low level. Similarly with the study conducted by $\mathrm{Wu}$ (2012) who showed that students in China ranging from the age of 10 to 12 years still have a low attitude and awareness toward environment. WWF-Malaysia (2009) also reports that the level of environmental literacy amongst the students in the United States, Singapore and New Zealand is between moderate and low. This finding is similar to Malaysian students' level of environmental literacy (Zurina \& Norjan, 2003; Ramli, 2003; Yusop et al., 2003; Ai Lin, 2004; Erdogan et al., 2009; Norjan et al., 2005; Norlila, 2007; Mageswary et al., 2006; Santha, 2008; Ismail, 2005). As a result Malaysia and other countries have continuously put efforts in developing environmental literacy amongst the students. Previously there have been efforts to establish the factors that affect the environmental attitude and behavior amongst the students in Ontario and the United States. Among the factors identified are gender and class stream in the environmental learning (Eagles \& Demare, 1999; Kellert, 1985; Muffit \& Eagles, 1990) have found that female students have better environmental attitude and behavior as compared to the male students. However, Kellert (1985) and Muffit \& Eagles (1990) have shown that there are no differences in terms of gender in the environmental education learning amongst the students. Ai Lin (2004) have found that students in the science stream in the secondary schools have shown higher level of environmental knowledge and attitude as compared to the students who are not in the science stream. Whereas a study by Tan \& Norzaini (2011) has shown that the level of environmental commitment amongst the university students in the pure science stream is lower as compared to the mean score of those in other streams of study, namely, the social science stream and the professional study stream. However, even though the level of knowledge of the science and non-science students is at a low and high level, the students from both streams of study show a positive environmental attitude.

Thus, in order to achieve a higher level of environmental literacy amongst the students, it is necessary to implement effective environmental lessons and teachers play a crucially important role to attain this aim (Goodnough \& Hung, 2008; Habibah \& Punitha, 2010). Effective teachers are those who possess the relevant content knowledge (Henze et al., 2008; Cutter, 2002), attitude towards the environment (Rohiza, 2004; Jimoyiannis, 2010b), and a deep pedagogical knowledge (Lilia et al., 2010; Mageswary, 2009) as well as able to teach effectively (Rosilawati \& Zainon, 2009; Sharifah, 2011). Pedagogical content knowledge is defined as a branch of teacher's knowledge that encomEEses both the knowledge related to the content and the implementation strategy which has been suitably designed to the specific teaching context (Mishra \& Koehler, 2006). This knowledge will help teachers to adapt their understanding with regards to the content into a good pedagogical form so that it is suitable to the ability and the background of the students (Shujie \& Lingqi, 2009). 
Meanwhile previous researches have also indicated that the teachers' attitude towards the teaching of environmental education is at the moderate and low level (Leeming et al., 1997; Eagles \& Demare, 1999; Norlila, 2007; Mageswary et al., 2006), so is the knowledge related to pedagogy and environment (Mageswary, 2009; Gess, 1999; Nor Aisyah \& Yap, 2002; Noor Azmi, 2003). Without therelevant knowledge and a positive attitude amongst the teachers, it is assumed that we may not achieve the desired aim and objective of EE.

In order, to achieve an effective teaching and learning of EE, teachers need to recognize their students in terms of knowing their background and their prior knowledge (Nur Akhmal, 2004), together with the students' misconception which happens in the process of learning (Mishra \& Koehler, 2006). The aforementioned teaching knowledge and skill is highlighted so that teachers can plan, implement and evaluate the teaching and learning (Mohd Zohir, 2008). Studies by (Mohd Zohir, 2008) show that teachers who make an early preparation before teaching are better prepared thus are able to motivate their students to learn, whereas lackadaisical teaching will cause the students to lose interest in learning and their confidence in the teachers will be considerably reduced. Nur Akhmal (2004) likewise postulated that learning should be suited to the students' cognitive capability and teachers should acknowledge the difficulty faced by the students in learning in order to avoid the occurrence of misconception (Mishra \& Koehler, 2006). Hence, teachers have the responsibility to rectify their students' misconception.

In implementing an effective teaching, teachers should also integrate various teaching strategies which are suitable to the interest, talent and cognitive level of the students (Rusilawati \& Zainon, 2009; Sharifah, 2011; Mohd Zohir, 2008; Khor, 2006). Teachers with effective pedagogical knowledge are capable of incorporating various teaching strategies that are suitable to the content taught. As argued by Mohd Zohir (2008), effective teaching depends on content knowledge and good delivery. However, in practice most teachers fail to select a suitable strategy that is relevant to the students' context, their gender and class stream. Most teachers do not attempt to see and do not even bother to identify the students' background, their cognitive level and their prior experience (Nur Akhmal, 2004; Khor, 2006).

Based on this problem, the researchers took the initiative to determine the level of environmental literacy among students in Malaysia by usingEE Kit. EE-Kit which have been developed are used by four of Pilot schools (1) Damansara Jaya Secondary School, Selangor, (2) Pinang Tunggal Secondary School, (3) Lanchang Secondary School Pahang and (4) Taman Kota Jaya Secondary School, Johor. Four pilot schools were known by the Sustainable School Environment Award - Curriculum components. Data on the level of environmental literacy and perception derived from the utilization of EE-Kit in four schools in Malaysia is still limited and has not been fully evaluated. Therefore the purpose of this study is to determine the differences in the level of environmental literacy among students based on gender and class stream and also students' perceptions about the use of EE-Kit.

\section{Conceptual Framework}

WWF-Malaysia $(2008,2009)$ collaborate with the Ministry of Education (MOE), the World Wild Fund (WWF) Malaysia together with various partners from local universities such Universiti Kebangsaan Malaysia, Universiti Malaya, Universiti Sains Malaysia and Universiti Putra Malaysia has developed and introduced an EE Kit with the purpose to assist teachers to teach environment effectively in schools. The EE Kit is a teaching module consisting of information which facilitates teachers in terms of knowledge and skill in teaching about environment. Four subjects chosen to use EE-Kit is Malay, English, Geography and Science at form 1 to form 3 for the Secondary School. The EE Kit also consists of three sections, namely, 1) conceptual, 2) hands-on activity and, 3) review. The difference between this EE Kit and other teaching modules is in its content, in which the content is explained by using power point presentation, games and issues found in magazines or newspapers and questions or puzzles. Another major difference is the availability of hands-on activities which provide the students opportunities to conduct research activities by themselves. The EE Kit was developed for teaching environment in lessons of the following subjects: Malay Language, English, Geography and Science for students from Form 1 to Form 3. In addition, each module is supplied with a DVD and/or a CD to complement the implementation of the EE Kit. 

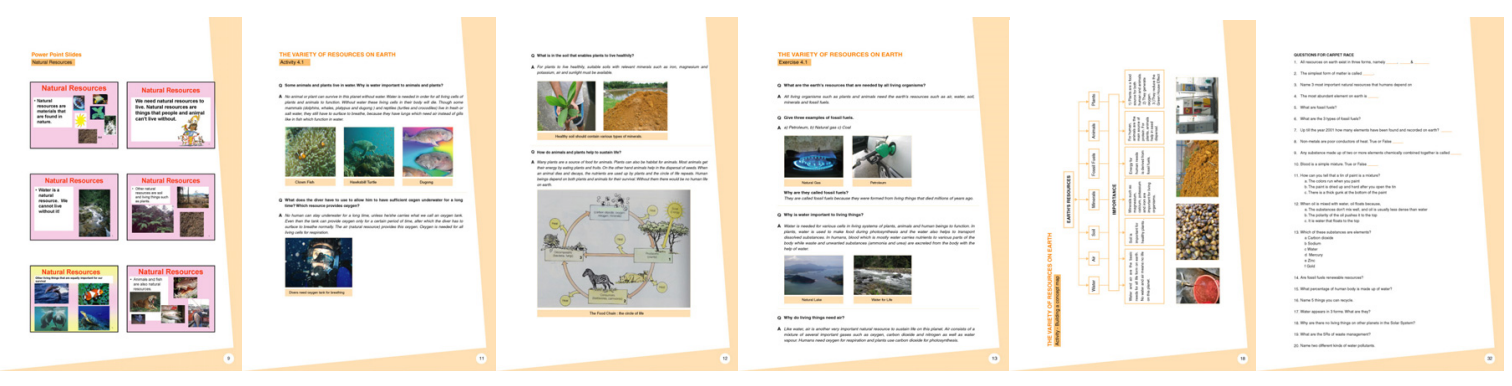

Figure 2. EE-Kit module

\section{Research Method}

\subsection{Research Design and Sample}

This research is conducted using qualitative and quantitative approaches. Qualitative data were collected through interviews with some of the students who have used EE-Kit in teaching and learning. The quantitative data was collected through a survey questionnaire. In this study, respondents for quantitative and qualitative studies involving the same sample. The questionnaire is aimed to identify students' level of environmental literacy and these students have been taught about environment using the EE kit. For the survey, 345 secondary school students from three schools (A, B, and C) were involved. For the qualitative study, the research sample consists of five students from each of the chosen schools to form a total of ten students for the interview study. The sample for this study was chosen amongst students from Form 2 and 4 (14 to 16 years old) and the sample was stratified based on gender and on the class stream there were in i.e. in the science or arts stream.

School A is situated in the rural area close to a river, oil palm and rubber plantation as well as nearby a jungle. The population in this school is 650 students and majority of them is Malay. Besides using the EE Kit, this school is also involved with the World Wild Life Fund (WWF) Malaysia, program, such as, the Eco School. Other eco-friendly activities conducted by this school are the construction of a herbal garden, rearing fish, creating vegetable plot, making an environmental construction kit, providing examination of on environment and recycling issues. As a result this school has attracted the interest of the media to help spread the environmental activities that had been conducted in the school. This school won the second place in the competition for being the most beautiful school in Temerloh in 2011.School B is located in a urban area and it is situated in a town surrounded by housing estates and shopping complexes. The school is compact; however, it is still green for it also full of trees, such as, palm trees, and flower which are planted within the school compound. The school has 1471 students with the majority of them is Chinese. School C is situated in a rural area in the northern zone of Peninsular Malaysia. There is a jungle behind the school and a housing estate is located on its left and front part of the school. With a student population of 1077, the majority of the student is Malay. Prior to using the EE kit, School $\mathrm{C}$ has integrated the environmental educational into the civic and Islamic religious lesson. With the EE kit program, EE is integrated in subjects of the Malay Language, English, Science and Geography. However, activities related to environment are still lacking in school $\mathrm{C}$, nevertheless teachers, occasionally, bring the students to visit agricultural parks and encourage students to set up and take care of the herbal garden.

\subsection{Instrument}

This study used two survey instruments, the interview protocols and questionnaires for students. Interview protocol consists of four open response items to ten students in rural schools that use EE-Kit. The interview items will include questions that confronted for their views on the environmental education (EE) in general that they have learned in EE-Kit that is (i) the perception of the environment, (ii) the perception of the importance of the environment, (iii) attitude towards the environment, (iv) knowledge about the environment. The questionnaire was adapted from previous questionnaires based on its construct suitability. Two main sections of this questionnaire are: section A deals with the respondents' background while section B consists of five constructs encomEEsing the component environmental literacy. The five constructs were: (1) Knowledge of and about environment, (2) attitude toward the environment, (3) environmental behavior, (4) Awareness of environmental issue, (5) involvement in environmental activities. The total number of items in section B is thirty five questions. For constructs one, the items are in the multiple choice form. Whereas the other four constructs were using the Likert scale from one to four. 


\subsection{Data Analysis}

In this research, the data were analyzed using the descriptive and inferential statistics. The independent $t$-test was used to analyze the differences of the level of environmental literacy among student based on gender and class stream. For the purpose of measuring the level of environmental literacy an interpretative scale was used where 1.00- 2.33 represent low, 2.34-3.66 moderate and 3.67-5.00 high.

\section{Findings}

Table 1. Demography of students

\begin{tabular}{lcc}
\hline \multicolumn{1}{c}{ Respondents } & Frequency & Percentage (\%) \\
\hline Male & 165 & 47.8 \\
Female & 180 & 52.2 \\
Form 2 & 198 & 57.4 \\
Form 4 & & \\
Science stream & 80 & 23.2 \\
Arts stream & 67 & 19.4 \\
Type of school & & \\
School A & 114 & 33.0 \\
School B & 101 & 29.3 \\
School C & 130 & 37.7 \\
\hline
\end{tabular}

As shown in Table 1,based on descriptive analyzed, This research was conducted on 345 students from three Secondary Schools located in Pahang, Kuala Lumpur and Kedah respectively. The EE kit was used in this school, where the demography of students represents $52.2 \%$ female and $47.8 \%$ male, $23.2 \%$ from Form 4 of science stream students and $19.4 \%$ arts stream students and $57.4 \%$ from Form 2 students.

\subsection{Level of Environmental Literacy among Students Based on Gender}

Table 2. The level of environmental literacy among students based on gender

\begin{tabular}{lccccccc}
\hline \multicolumn{1}{c}{ Construct } & Gender & Mean & Interpretation & Sdv & $\mathrm{t}$ & $\mathrm{df}$ & $\mathrm{Sig}$ \\
\hline Knowledge of and about environment & Male & 1.42 & Low & 0.28 & & & \\
& Female & 1.32 & Low & 0.30 & 2.92 & 343 & $0.004^{*}$ \\
Environmental Behaviour & Male & 2.51 & Moderate & 0.36 & & & \\
& Female & 2.55 & Moderate & 0.31 & -1.09 & 343 & 0.276 \\
Environmental Involvement & Male & 2.80 & Moderate & 0.49 & & & \\
& Female & 2.75 & Moderate & 0.50 & 0.92 & 343 & 0.361 \\
Attitude towards the environment & Male & 3.14 & Moderate & 0.69 & & & \\
Awareness on of environmental matters & Female & 3.32 & Moderate & 0.45 & -2.95 & 343 & $0.003^{*}$ \\
& Male & 3.15 & Moderate & 0.61 & & & \\
& Female & 3.29 & Moderate & 0.45 & -2.49 & 343 & $0.013^{*}$ \\
\hline
\end{tabular}

From the analysis, it can be seen that for each construct the level of environmental literacy based on gender is found to be still at moderate and low level. It appears that no construct has a high mean value. The research also shows that the mean value for male is slightly lower than female for four constructs, except for one construct which shows the reverse, namely, the construct on knowledge on and about environment.

However, based on inferential analysis, the $\mathrm{p}$ value obtained for the following constructs i.e. environmental behavior and involvement in environmental activities exceed $0.05(\mathrm{p}=0.276, \mathrm{p}=0.361)$ respectively. This finding 
indicates that there is no significant difference for those construct among students based on gender. Whereas, the $p$ value for the knowledge of and about environment $(p=0.004)$, attitude towards the environment $(p=0.003)$, awareness of the environmental issues $(p=0.013)$ are less than the significant value $(0.05)$. These indicate that there are significant differences amongst the students based on gender. Overall, even though the difference in the mean values is small for all construct, yet the inferential analysis using the independent $t$ test indicates that the differences are significant.

\subsection{Level of Environmental Literacy among Students Based on Class Streams}

Table 3. The level of environmental literacy among students based class streams

\begin{tabular}{|c|c|c|c|c|c|c|c|}
\hline Construct & Stream & Mean & Interpretatiom & $\mathrm{sdv}$ & $\mathrm{t}$ & $\mathrm{df}$ & Sig \\
\hline \multirow[t]{2}{*}{ Knowledge of and about environment } & Science & 1.27 & Low & 0.28 & & & \\
\hline & Arts & 1.34 & Low & 0.31 & -1.59 & 145 & 0.114 \\
\hline \multirow[t]{2}{*}{ Environmental behavior } & Science & 2.49 & Moderate & 0.23 & & & \\
\hline & Arts & 2.51 & Moderate & 0.35 & -2.60 & 145 & 0.796 \\
\hline \multirow[t]{2}{*}{ environmental involvement } & Science & 2.83 & Moderate & 0.40 & & & \\
\hline & Arts & 2.73 & Moderate & 0.58 & 1.29 & 145 & 0.201 \\
\hline \multirow[t]{2}{*}{ Attitude towards the environment } & Science & 3.28 & Moderate & 0.55 & & & \\
\hline & Arts & 3.31 & Moderate & 0.58 & -0.41 & 145 & 0.681 \\
\hline \multirow[t]{2}{*}{ Awareness on environmental matters } & Science & 3.26 & Moderate & 0.46 & & & \\
\hline & Arts & 3.26 & Moderate & 0.52 & 0.02 & 145 & 0.987 \\
\hline
\end{tabular}

As seen in Table 3, comparison of the mean value for all construct of environmental literacy did not show a high trend among students based on class streams. It was indicated means value in the level of environmental attitude, knowledge, behavior, awareness and involvement among students is still at the moderate and low level.

\subsection{Students' Perceptions about the Use of EE-Kit}

Based on the interviews that were conducted on 10 students, the study found that male students have better knowledge and perception towards EE compared to female students. For the knowledge of the EE, the male students said that they have heard about environmental educations which have been conducted in their schools. Male students also found out about the importance of environmental education and give positive view of the importance of the EE in school. However, the two female students were not aware of the existence of EE to increase students' awareness of the environment. They have heard about EE, but do not know the true meaning of $\mathrm{EE}$ and the importance of $\mathrm{EE}$ to preserve and conserve the environment. Therefore, the effectiveness of EE should be enhanced to reduce EE-Kit usage gap among students in schools. EE-Kit has to be done extremely well planned and organized, and involved all male and female students to increase students' awareness of their responsibility to the environment.

Therefore, although most of the students have a positive perception of EE, majority of them are male students. They agree and appreciate the EE implementation in schools and recognize the importance of EE in enhancing students' awareness of environmental problems and issues that are happening around them. Male students also said EE implementation through cross-curricular elements is enough and able to bring awareness to them. However, there are female students who do not quite agree on this. They argue that EE has been implemented at the school are still not complete enough to provide the knowledge and exposure to the students about the environment. They also felt that a special subject of the environment should be created in schools in order to achieve EE objectives to maintain environmental sustainability since primary school.

\section{Discussion}

\subsection{Level of Environmental Literacy among Students Based on Gender}

Based on independent $t$ test analysis, it was identified that differences occur based on gender. As for knowledge of and about environment, male students have a higher mean value as compared to the female. Whereas the others four construct, the female showed a higher level of environment attitude, behavior, awareness and involvement in environmental activities as compared to the male. These findings are supported by Eagles \& 
Demare (1999) who found that female students had a higher level of environment attitude and behavior as compared to the male students. Nonetheless, the finding in this research is contrary to the research listed by Kellert (1985) and Muffit \& Eagles (1990) who showed that there was no differences between gender in the environmental learning among students. This finding portrays that teaching about environment by using EE Kit has proven that female are more keen to learn and to understand the environment than male students. This is also in consensus with the finding of WWF-Malaysia $(2008,2009)$ that the achievement of the female exceeds the male in learning about environment. Thus, there is a tendency to assume that the female students' environment attitude, behavior and involvement in environmental activities are higher as compared to male as supported analytically in this research.

\subsection{Level of Environmental Literacy among Students Based on Class Streams}

Comparison of the mean value for all construct of environmental literacy among students based on class streams did not show a high trend among students based on class streams. It was found that the means value for all construct in the level of environmental literacy among students is still at the moderate and low level. These finding is similar to previous studies by (Ridener, 1997; Wu, 2012; Ramli, 2003; Mohd Yusof \& Ahmad, 2003; Ai Lin, 2004; Norjan et al., 2005; Norlila, 2007; Mageswary et al., 2006; Santha, 2008; Khor, 2006) in that level of environmental literacy among students was still low and moderate level. Although the knowledge of students in the science stream and arts stream is still low, however students from both streams have shown a positive attitude towards the environment. Students from science stream have a higher awareness of environmental issues compare to the arts stream students. This high awareness among science student could be due to more exposure to environmental issues through science subject compare to arts students. This finding is consistent with the previous study by Ai lin (2004) who found that the level of environmental knowledge of and about environment, environment attitude and behavior of Secondary School students in the science stream was higher than those in the non-science stream. The study by Norjan et al. (2005) also found that students from the science stream had a higher environmental attitude.

However, Tan \& Norzaini (2011) found that the mean score towards the environmental commitment among university students in the Pure Science stream was lower as compared to the mean score among students of other study streams, such as, the social science stream and the professional stream. As explained in this study, from the inferential analysis, independent $t$ test indicates that there is no significant difference of mean for each construct in the level of environmental literacy among students based on class streams is less than the significant value $0.05(\mathrm{p}<0.05)$. That means there are no significant differences between mean values for all construct in the level of environmental literacy among students science stream students and arts stream students. It appears that no significant difference between students in science and arts streams could be due to the strategy of learning in the EE kit is the same for both types of students.

\subsection{Students' Perceptions about the Use of EE-Kit}

Students'Perception towards EE: Students' perception towards EE which have learned in EE-Kit and have run across the curriculum through subjects such as Science, Geography, English and Bahasa Melayu is the first theme available. It shows students' opinions and views on EE. One item was forwarded to the student: You have to use EE-Kit in Science, Geography, English and Bahasa Melayu since school began earlier this year. Is the message of environmental education in all four subjects is sufficient to raise the awareness and understanding of local environmental problems. The interviews showed that most students have a good perception on EE. Here is the interview obtained in this study:

"It is very helpful, since EE-Kit have environmental content that provides opportunities for students to care for the environment and students can engage in environmental hands-on activities creatively" (P6, P3 and P9).

"It is enough because EE-Kit provide awareness towards environment" (P1).

"Yes. EE-Kit is enough to raise awareness and understanding of environmental problems because in it there are activities and games that allow students to work in groups" (P2, P5 and P10).

"I think the message in EE-Kit in all four subjects is sufficient to raise the awareness and understanding of local environmental problems" (P4 and P8)

There is only one student stated EE-Kit still is not enough to increase students' environmental awareness. These findings were derived based on the interview follows.

"It may be enough, some lessons can be understood, some not" (P3).

Generally, students have a positive perception towards EE. However, there were some who expressed learning 
through EE-Kit only is not enough to increase students' environmental awareness. Hence, the learning should be widely implemented and is not limited to EE-Kit. All peoples must cooperate and work together for the success of EE in school.

Students' Perception Towards The Importance Of Environment: In this interview, students' perceptiontowards the importance of environment is the second theme that shows the opinion or views of students about the importance of the environment. One item was forwarded to the student: Is it important to preserve the environment?. The findings from the interviews $(n=10)$ showed that all students have a positive view of the importance of the environment. Here is the interview script obtained from ten students interviewed:

"The environment is important in the future, and for the good of future generations." (P1 and P5)

"The environment is very important because that future generations can experience the beauty of nature." (P3)

"It is important, because the environment is one of the most precious and unique gift from Allah. Therefore, we as a today generation should protect and conserve the environment in order to be EEsed on to future generations." (P2, P6, P7, and P10)

"The environmental preservation is very important so that future generations can live comfortably without any environmental pollution." (P4, P8, and P9)

Generally, all students in rural schools who uses EE-Kit has a positive view on the environment. They realize the importance of the environment and stated the need for protection to the environment so that future generations can enjoy the beauty of the environment.

Knowledge about EE: Students' knowledge about EE is the third theme raised. It shows their knowledge about EE conducted at their school after learning to use EE-Kit. One item was forwarded to the students: Have you ever heard about environmental education? What is the meaning of environmental education? The results showed the majority of students had poor knowledge about EE. Here are some excerpts of the interview was obtained in this study.

"Environmental education is to learn something about the environment".

"I've heard about EE. EE is the knowledge of the natural surroundings."

"EE is education on awareness and exposure to the public about the importance of the environment".

"Yes, EE means applying the lessons of awareness'elements of the importance of protecting the environment."

However, there are some students who do not know about EE conducted in their schools. This finding is based on a number of the interview obtained in this study.

"I have heard this, in the subjects of geography, thinning ozone layer caused by factories and vehicles'smog, but do not know its meaning".

"I've heard about it, but do not know what that means".

Generally, the data obtained showed that the majority of students still have a low content knowledge about the environment that have been conducted in schools through the use of EE-Kit. There was even students who are not sure and do not know the exact content of EE. Therefore, all parties including teachers and parents should play their role to the successful implementation of the EE. EE success will benefit the environment in our country.

Students Attitudes towards the Environment: Fourth theme is about students' attitudes. One item was forwarded to the students: What environmental changes you want to do in your school having learned EE through EE-Kit? The interviews show all study participants had a positive attitude towards the environment. Here are some excerpts of the interview were obtained:

"Providing environmental awareness campaign and hygiene school campaign" (P1 and P3).

"I want all the students do not throw litter in the school" (P2).

"Ask a lot of trees planted and run the 3R program, recycling programs" (P4, P5 and P8).

"Using recycled materials to decorate the school" (P6 and P9).

"EE changes I want to do is to plant various species of trees to increase my knowledge about the trees and its scientific names" (P7 and P10).

Generally, rural students who use EE-Kit has a positive attitude towards the environment. They have a good plan to make environmental changes in their schools. 
Based on the above analysis of the interviews, most students have a positive perception of the use of EE-Kit. In terms of the importance of EE-Kit to the environment, two interview excerpts have shown that students' perceptions of good and positive: "It is very helpful, since EE-Kit have environmental content that provides opportunities for students to preserve the environment and students can engage in the environmental hands-on activity creatively" (P6, $\mathrm{P} 7$ and $\mathrm{P} 9)$ and "Enough because through EE-Kit provide awareness associated with the environment" (P1). Based on this EEsage, students have agreed and confirmed the importance of EE-Kit by provide opportunity and engage students in a variety of exciting activities that contribute to the preservation of the environment. Besides that, EE-Kit have also raised environmental awareness among the students to be more responsible and having a life that supports the EEsage of time and does not go against the environment. However, there are students who do not agree and said: "It may be enough, some lessons can be understood, some not" (P3). The Student felt that EE was carried out by elements across the curriculum is not enough and a special subject of the environment should be created to instill awareness in students. Thus, EE should be implemented effectively, especially in rural schools that have more limited facilities and access than urban schools for the benefit of all parties.

In the analysis of the importance of environment, most students have a positive perception of the importance of the environment. Based on the three interview excerpts; "The environment is very important because that future generations can experience the beauty of nature" (P3), "It is important, because the environment is a most precious and unique gift from Allah. Therefore, we as a today generation should preserve and conserve the environment in order to be EEsed on to future generations" (P2, P6, P7, and P10) and "Preserve the environment is very important so that future generations can live comfortably without any contamination environment"'(P4, P8, and P9), majority of the students are aware of the importance of the environment. They felt that the environment should be preserved well to be EEsed on to the future generations. Therefore, the implementation of EE which aims to preserve the environment should be improved and implemented as good as possible for the benefit of the present generation and the future generation.

The findings also showed that students had poor knowledge of EE. Based on two interviews: "I have heard this, in the subjects of geography, thinning ozone layer caused by factories and vehicles' smog, but do not know its meaning" and "I've heard about it, but do not know what that means", students have less knowledge about EE and do not concerned about EE implementation in their schools. They just heard about EE but not moved to learn more about EE. Consequently, EE campaigns and promotions should be enhanced to provide exposure and information about EE to students.

Further, majority of the students show positive attitude towards the environment and can be proud of. All students who were interviewed have a positive attitude and have a good plan to improve the cleanliness and beautifying their school. Based on the interview: "Providing environmental awareness campaign and hygiene school campaign", an awareness campaign can increase students' awareness of the environment began in their school. Recycling is also a great step to reduce waste production and improve the cleanliness of the school as in the interview: "Ask a lot of trees planted and run the $3 R$ program, recycling programs". Thus, each student's proposal and plan should be considered and evaluated by the school to improve the school cleanliness and cheerful.

\section{Conclusion}

Overall it was found that the level of environmental literacy among students based on gender and class stream are at moderate and low level. Further investigation is needed to address why students obtained so poorly. However, the research also shows that there is a significant difference in the level of environmental literacy based on gender. While, class stream did not contribute significantly to explaining the level of environmental literacy. It is appears that any intervention such as EE kit should promote students to carry out hands on activities. The activities in EE kit should relate to the activities liken by the male students. Currently, the activities which is more on powerpoint presentation which is still classroom based appear to encourage girls to be more contentious towards environment. Perhaps the EE kit activities should be more outdoor activities oriented which not only encourage boys to be interested but also the girls. Students also have a positive perception of the use of EE-Kit but their knowledge about the environment which is taught through EE-Kit is on low level. Therefore, the effectiveness of EE-Kit should be enhanced to increase the level of environmental literacy among students to address environmental issues in Malaysia. All parties, including teachers and communities should work together and cooperate with each other for the success of EE-Kit implementation in the school. Increase the level of environmental literacy will help the process of preservation and conservation of the environment for the future generations. 


\section{References}

Ai Lin, E. (2004). A Study of Environmental Awareness Knowledge and Attitude towards Tropical Rainforest Issues among Melaka Secondary School Students. Unpublished Doctoral Thesis. University of Malaya.

Callicott, J. B. (2000). Harmony between Man and Land. Aldo Leopold and the Foundation of Ecosystem Management. Journal of Forestry, 98(5), 4-13.

Eagles Paul, F. J., \& Demare, R. (1999). Factors Influencing Childrens' Environmental Attitudes. The Journal of Environmental Education, 30(4), 33-37. http://dx.doi.org/10.1080/00958969909601882

Erdogan, M., Kostova, Z., \& Marcinkowski, T. (2009). Components of environmental litercy in elementary Science Education curriculum in Bulgaria and Turkey. Eurasia Journal of Mathematics, Science and Technology Education, 5(1), 15-26.

Erdogan, M., Kostova, Z., \& Marcinkowski, T. (2009). Components of environmental literacy in elementary science education curriculum in Bulgaria and Turkey. Eurasia Journal of Mathematics, Science, and Technology Education, 5(1), 15-26.

Goodnough, K. C., \& Hung, W. (2008). Engaging teachers' pedagogical content knowledge: Adopting a nine-step problem based learning model. Interdisciplinary Journal of Problem-based Learning, 2(2). http://dx.doi.org/10.7771/1541-5015.1082

Habibah, L., \& Punitha, M. (2009). Environmental Education: Current curriculum situational and the challenges at Primary School, Malaysia. Introducing "Spatial Thinking" to Geography Education. Tsukuba Conference. August $6^{\text {th }}$ to $8^{\text {th }}$.

Habibah, L., \& Punitha, M. (2010). Environmental Education (EE): Current situational and the challenges among trainee teachers at teachers training institute in Malaysia. WCES. Procedia Social and Behavioral Sciences, 2(2), 1896-1900. http://dx.doi.org/10.1016/j.sbspro.2010.03.1005

Henze, I., van Driel, J. H., \& Verloop, N. (2008). Development of experienced science teachers' pedagogical content knowledge of models of the solar system and the universe. International Journal of Science Education, 30(10), 1321-1342. http://dx.doi.org/10.1080/09500690802187017

Ismail, H. (2005). Environmental education awareness among secondary school students in Jerantut, Pahang. Unpublished Doctoral Thesis. National University of Malaysia.

Jamil, A. (2002). Research culture among school teacher. Unpublished Doctoral Thesis. National University of Malaysia.

Jimoyiannis, A. (2010). Developing a Technological Pedagogical Content Knowledge Framework for Science Education: Implications of a Teacher Trainers' Preparation Program. Proceedings of Informing Science \& ITEducation Conference (InSITE).

Kellert, S. R. (1985). Attitude towards Animals. Age Related Development among Children. The Journal of Environmental Education, 16(3), 29-39. http://dx.doi.org/10.1080/00958964.1985.9942709

Khor, C. Y. (2006). Environmental education Awareness among preschool teachers in di Pulau Pinang. Unpublished Master's Thesis. University Putra Malaysia.

Leeming, F. C., Porter, B. E., Dwyer, W. O., Cobern, M. K., \& Oliver, D. P. (1997). Effect of Participation in Class activities on Childrens' Environmental Attitude and Knowledge. The Journal of Environmental Education, 28(2), 33-42. http://dx.doi.org/10.1080/00958964.1997.9942821

Lilia, H., Nuraznan, M., \& Arba'at, H. (2010). Environmental education assessment toward environmental literacy among preservice teachers. Proceeding postgraduate research Seminar. National University of Malaysia.

Mageswary, K. (2009). The effect of the green chemistry experiments on environmental values and knowledge and chemistry concepts among pre-service teachers. Ph.D. Universiti Sains Malaysia.

Mageswary, K., Zurida, I., \& Norita, M. (2006). Knowledge, belief, desires and behavior of chemistry pre-service teachers towards the environment. Proceeding of the 2006 International Organization of Science and Technology Education, 487-494.

McBecth, B., \& Volk, T. (2010). The National Environmental Literacy Assessment Project: A baseline study of middle grade students in the United States. The Journal of Environmental Education, 41(1), 55-67. http://dx.doi.org/10.1080/00958960903210031 
McBecth, W., Hungerford, H., Marcinkowski, T., Volk, T., \& Meyers, R. (2008). National Environmental Literacy Assessment Project: Year 1: National baseline study of middle grades students. Final report. Bethesda, MD: NOAA.

Mcdonald. J. T., \& Dominguez, L. A. (2010). Professional Preparation for science Teachers in Environmental Education. In A. Bodzin, B. S. Klein, \& S. Weaver (Eds.), The Inclusion of Environmental Education in Science Teacher Education. Retrieved February 12, 2012, from http://www.springer.com/education+\%26+language/science+education/book/978-90-481-9221-2

McKeown, R. (2002). Education for Sustainable Development Toolkit. Retrieved April 2, 2012, from http://www.esdtoolkit.org/esd_toolkit_v2.pdf

Mishra, P., \& Koehler, M. J. (2006). Technological Pedagogical Content Knowledge: A Framework for Integrating Technology in Teacher Knowledge. Teachers College Record, 108(6), 1017-1054. http://dx.doi.org/10.1111/j.1467-9620.2006.00684.x

Mohammad, Z. A. (2008). Implementation of Environmental Education in Geography Subject at Secondary School: Teachers' Knowledge, Attitude, Efficacy and Practices. Unpublished Doctoral Thesis. National University of Malaysia.

Moroye, C. M. (2005). Common Ground: An Ecological Perspective on Teaching and Learning. Curriculum and Teaching Dialogue, 7(1-2), 123-139.

Muffit, S., \& Eagles, P. F. J. (1990). An Analysis of Childrens Attitudes toward Animals. The Journal of Environmental Education, 21(3), 35-41.

Negev, M., Sagy, G., Garb, Y., Salzberg, A., \& Tal, A. (2008). Evaluating the environmental literacy of Israeli elementary and high school students. The Journal of Environmental Education, 39(2), 3-20. $\mathrm{http}: / / \mathrm{dx}$.doi.org/10.3200/JOEE.39.2.3-20

Noor Shah, S. (2009). Mathematics Student Teachers' Pedagogical content Knowledge in the Context of Teacher Education Programs. In O. De Jong, \& H. Lilia (Eds.), Teachers' Professional Knowledge in science and Mathematics Education: Views from Malaysia and Abroad. Selangor: Faculty of Education, National University of Malaysia.

Nor Aisyah, B., \& Yap, P. M. (2002). Teachers competence in Kuala Lumpur in the knowledge and attitude toward entrepreneurship teaching. Teknologi Journal, 36(E), 1-16.

Norjan, Y., Nur Ibtisam, I., Rohana, S., \& Rohayati, M. (2005). Knowledge and awareness toward environmental education among students. National Seminar Proceeding on environment. Bangi: National University of Malaysia.

Norlila, T. (2007). Implementation of Environmental Education at Secondary School in Seremban. Unpublished Master's Thesis. National University of Malaysia.

North America Association for Environmental Education (NAAEE). (2001). Using Environment- Based Education to Advance Learning Skills and Character Development. A report, Annotated Bibliografi, and Research. Washington: NEE \& Training Foundation.

Perikleous, E. (2004). The Status of Environmental Education in Cyprus Today. In MIO-ECSDE. The status of environmental education in the mediterranean coutries within theformal \& non-formal educational systems. Dec, Issue No. 34.

Raczynski, D., \& Munoz -Stuardo, G. (2007). Chilean Educational Reform: The Intricate Balance between a Macro and micro Policy. In W. T. Pink, \& G. W. Noblit (Eds.), International Handbook of Urban Education. Retrieved from http://www.bligoo.com/media/users/2/113704/files/latin\%20America,\%20Raczynski\%20and\%20Munoz-St uardo.pdf

Ramli, S. (2003). Environmental knowledge among preservice teachers in kolej of education Raja Melewar Negeri Sembilan, Malaysia. Unpublished Master Thesis. National University of Malaysia

Ridener. (1997). University Students Attitude to the Environment.An Australian/ USA Comparison and the Effects of an Educational Program. Australia Journal of Environmental Education, 13(1), 77-84.

Rusilawati, O., \& Zainon, A, M. (2009). Pedagogical Content Knowledge in the Malaysian School Science Curriculum. In O. De Jong, \& H. Lilia (Eds.), Teachers' Professional Knowledge in science and Mathematics Education: Views from Malaysia and Abroad. Selangor: Faculty of Education, national 
University of Malaysia.

Santha, L. (2008). Environmental Education across Curriculum: A study of 5R Practices among Form 6 Students in Kluang, Johor. Unpublished Master's Thesis. National University of Malaysia

Sharifah, I. S. (2011). Teachers pedagogical Content Knowledge in environmental education. Unpublished Master's Thesis. National University of Malaysia

Shujie, L., \& Lingqi, M. (2009). Perception of Teachers, Students and Parents of the Characteristics of Good Teachers: A Cross-cultural Comparison of China and the United State. Educational Assessment, Evaluation and Accountability, 21(4), 313-328. http://dx.doi.org/10.1007/s11092-009-9077-z

Smith, S. N. J. (2007). A Reinvestigation of Teachers Motivations towards and Perceptions of Residential Environmental Education: A Case Study of the new Jersey School of Conservation. The Journal of Environmental Education, 38(4), 34-42. http://dx.doi.org/10.3200/JOEE.38.4.34-42

Talero, G. (2004). Literature Review. Environmental Education and Public Awareness. Canada: Victoria.

Tan Pei, S., \& Norzaini, A. (2011). The Relationship between Commitment towards Environment and Pro-environment Behavior among University Students. Journal of Student Personalia, 14, 11-22.

Taraban, R., Box, C., Myers, R., Pollard, R., \& Bowen, C. W. (2007). Effects of Active-Learning Experiences on Achievement, Attitudes, and Behaviors in High School Biology. Journal of Research in Science Teaching, 44(7), 960-979. http://dx.doi.org/10.1002/tea.20183

Van Driel, J. H., \& Berry, A. (2010). Pedagogical content knowledge. International Encyclopedia of Education, 656-661. http://dx.doi.org/10.1016/B978-0-08-044894-7.00642-4

$\mathrm{Wu}$, L. (2012). Exploring the New Ecological Paradigm Scale for Gauging Children's Environmental Attitudes in China. The Journal of Environmental Education, 43(2), 107-120.

WWF-Malaysia. (2008). Strengthening Environmental Education in existing National Curriculum. Malaysia. WWF-Malaysia.

WWF-Malaysia. (2009). Environmental Citizenship: A Report On Emerging Perspectives in Malaysia. Malaysia. WWF-Malaysia.

Yusuf, M. A. H., Jailani, M. Y., \& Ahmad, E. (2003). Knowledge, practice and attitude toward environmental education among student. National seminar Prosidingof environment. Bangi. National University of Malaysia.

Zurina, M., \& Norjan, Y. (2003). Environment awareness among students at National University of Malaysia. NationalseminarProsiding on environment. Bangi: National university of Malaysia.

\section{Copyrights}

Copyright for this article is retained by the author(s), with first publication rights granted to the journal.

This is an open-access article distributed under the terms and conditions of the Creative Commons Attribution license (http://creativecommons.org/licenses/by/3.0/). 